\title{
Development of Chemical Practicum Private Vocational School of Senior High School XII Class Based on Projects and Characters
}

\author{
Bajoka Nainggolan \\ Department of Chemistry, Faculty of Mathematics and \\ Natural Sciences, Universitas Negeri Medan, \\ Medan, Indonesia \\ Email: nainggolanbajoka@gmail.com
}

\author{
Rianto Sitanggang, Wesly Hutabarat \\ Department of Chemistry, Faculty of Mathematics and \\ Natural Sciences, Universitas Negeri Medan, \\ Medan, Indonesia \\ Email: barathuta@gmail.com
}

\begin{abstract}
This research is descriptive with the aim of developing project-based chemistry practicum guides and the characters of Redox and Electrochemical Reaction materials according to BSNP standards. The sample consisted of 2 lecturers and 2 chemistry teachers, 30 students experimental class and 30 students control class at the Medan ${ }^{\text {th }}$ Senior High School, three practicum guides of Erlangga (A) publishers, Bumi Aksara (B), Duta Nusantara (C),. The study used the ADDIE method and the data was processed descriptively. Questionnaires distributed to the leacturer and teacher samples and found that content, language, presentation, and graphycs feasibility scores were 3.53., 3.46., 3.50., and 3.53 respectively, the average score was 3.32., which means that the practicum guide developed is very valid. Data analysis with ANOVA, obtained the average scores of student outcomes in experimen class was higher than control class or $81.5 \%>73.8 \%$. Then the average phsychomotor scores of experimen class was larger than control class or 84, $64>82.78$. In addition, the affective scores of experimen class was larger than control class or $78.42>\mathbf{7 6 . 3 8}$. The hypothesis tested with one way ANOVA at the significant level of $\alpha \mathbf{0 . 0 5}$, and found that $t_{\text {count }}>t_{\text {table }},(4.536>1.697)$. It is concluded that the Innovative Chemistry Practicum Guides developped is highly very good, suitable for use in Senior High School.
\end{abstract}

Keywords-Practicum Guides Project-Based and the Characte; Learning Outcome; Redox and Electrochemical Reaction

\section{INTRODUCTION}

Basically the application of the 2013 curriculum in learning has been designed and designed in such a way through the scientific approach (scientific method) and contextual (contextual method), with the hope that students who are taught have balanced competencies between attitude, knowledge and skills which is far better than before. Chemistry is one of the science subjects in the 2013 curriculum at the level of high school education. Many students have difficulty learning chemical concepts because they have complex and abstract characteristics. One of the chemical competencies that must be possessed by students of class XII High School Science is understanding the concept of Redox and Electrochemical Reactions, which are categorized as material that is difficult for students to understand because of the scope and flexibility of the material, project based learning in forming innovative characters effective, creative, and productive.

Learning innovation is important in an effort to change the teacher's learning center to student-centered and structured learning, to improve student mastery in the concept of science with the impression that participants can remember more and more students [1]. Innovations that are successfully used in chemistry learning include learning innovations with laboratory and non-laboratory activities, using media innovation, and information technology-based learning innovations [2].

In [3] research, learning innovation that can be done in character building is a Project Based Learning model, which is an innovative learning model that involves project work, where students work independently or in a group in constructing their learning and summarizing the product real. Chemistry is experimental science, so learning activities must be integrated with practice to build students' knowledge of the material being studied [4]. The reason for the importance of integrated learning practice is because it can increase student motivation, improve basic skills in experimentation, become a scientific learning tool to support the understanding of subject matter.

One of the obstacles experienced by teachers in schools in chemical learning is the existence of inadequate practical guides [5]. The circulation of practicum guides from various printouts used by students in schools, still lacks an impact on project-based learning models and innovative and integrated character practices according to the 2013 curriculum. Given the importance of project-based practicum guides and characters in learning, it is necessary to develop innovative chemistry practicum guides that meet BSNP standards (Education National Standards Agency) to be used for XII grade high school science students, and as practicum guide books for chemistry teachers. So that in this study an innovative project-based chemistry practicum guideline development and high school class XII characters were 
developed in the Redox and Electrochemical Reaction material.

\section{RESEARCH METHOD}

The research was conducted at the Medan $6^{\text {th }}$ Public High School. The development of chemical practicum guide on Redox and Electrochemical Reactions used the ADDIE method [6]. Three chemical practicum guide samples selected from three local publishers were Gramedia (A), Bumi Aksara (B) and Duta Nusantara (C), 2 Unimed chemistry lecturers, 2 chemistry teachers, 2 classes in Medan $6^{\text {th }}$ Senior High School. Class XII-2 Science (experimental class) was given integrated practice teaching practice using development chemical practicum guide results, class XII IPA-4 (control class) was taught using student handbooks.

Stages of research include (1) analysis of syllabus and Chemical Practicum Guide, (2) design (3) development Chemical Practicum Guide and revisions, (4) implementation, (5) data evaluation and analysis. Overall the research procedure is as shown in Figure 1 and Figure 2.

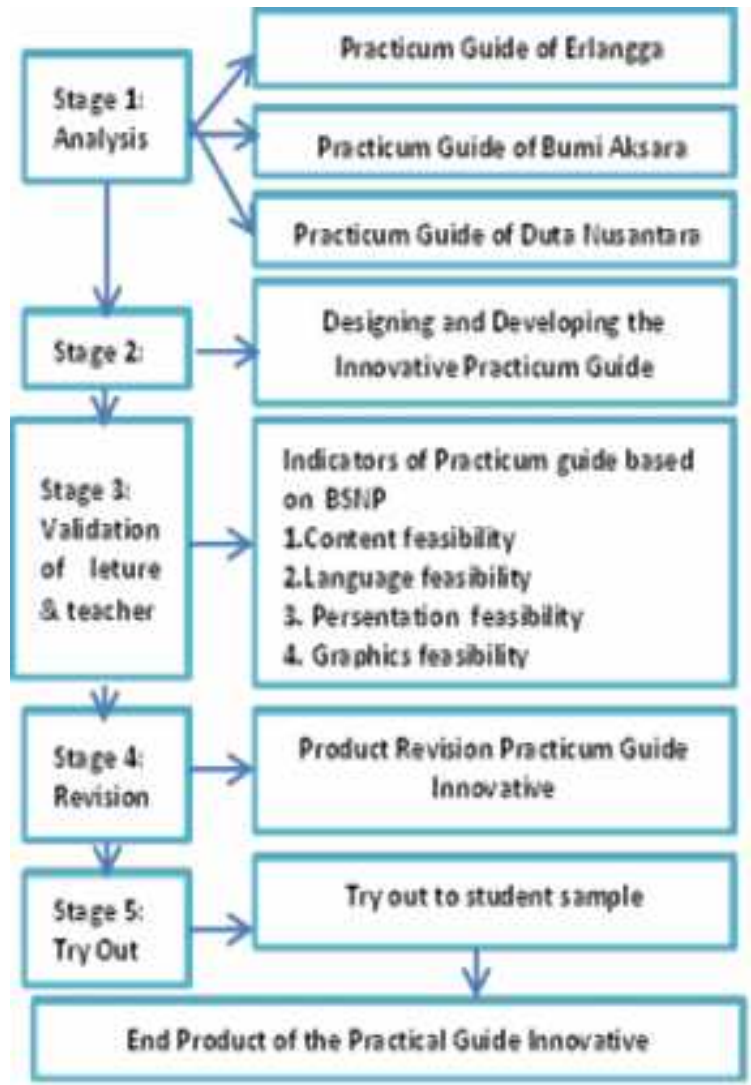

Fig. 1. Practicum guide Development Steps Treatments
During the research stage, sillabus analysis and practicum guides $\mathrm{A}, \mathrm{B}$, and $\mathrm{C}$. Then the design and development became innovative project-based practicum guides and characters, validation of content feasibility, language feasibility, presentation feasibility and graphic feasibility with BSNP standard assessment instruments on Likert scale score 1 to 4 , with criteria: 3.26 - 4.00, very valid, no need for revisions, 2.51-2.50, valid, no need revision, 1.76-2.50, less valid, partial revision, and 1,00-1,75, invalid, total revision [7 ]

The data analysis technique used is the average technique with the formula:

$$
\begin{gathered}
\bar{X}=\frac{\Sigma X}{\bar{a}}, \text { where : } \\
\bar{X}=\text { average; } \\
\Sigma X=\text { total scores }
\end{gathered}
$$$$
\mathrm{n}=\text { number of validators }
$$

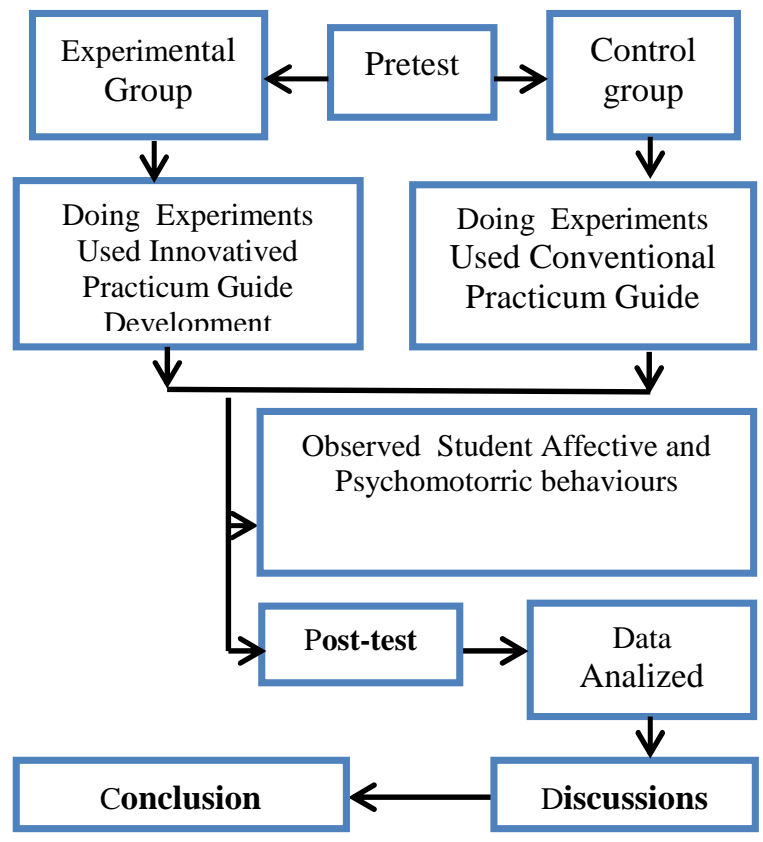

Fig. 2. Try out of the Chemistry Practicum Guide Analysis

Practical guiding trials of the results of the development to 30 samples of students in the experimental class, while 30 samples of students for the control class used the student's practical guidance guide. Before the pre-learning session, a pre-test was carried out, followed by integrated project-based learning in the Redox and Electrochemical Reaction material practicum, then post-test was held. The research design is as shown in table 1 [8].

TABLE 1 RESEARCH DESIGN

\begin{tabular}{cccc}
\hline Groups & Pre-test & Treatment & Post-test \\
\hline Eksp. & T1 & X1 & T2 \\
Control & T1 & X2 & T2 \\
\hline
\end{tabular}


$\mathrm{X} 1$ = Learning using developmental Practical Guide (experimental class)

X2 = Learning using student handbook Practicum Guide (control class)

$\mathrm{T} 1=$ pre test; $\mathrm{T} 2=$ Post test

During learning, student activities were observed by 4 observers using affective and psychomotor assessment rubrics. Data analysis was viewed from aspects of knowledge, attitudes, and skills. For the aspect of knowledge seen from the increase in gain, aspects of attitude and skills use the assessment rubric. Qualitative data in the form of questionnaires obtained from the validator team and quantitative data obtained through pre-test and post-test to the sample. Student activity data was obtained through 4 observer observations during the treatment of samples. The normality test with Chi-square at the real level $\alpha=0.05$ with the criteria:

If the Chi-squared $\left(\chi^{2}\right)_{\text {calc. }}<\left(\chi^{2}\right)_{\text {table }}$ then the samples were normally distributed. Validity test was carried out using the following formula

$$
\mathrm{F}_{\mathrm{cal}}=\frac{\text { Huga Variance }}{\text { low Vonance }} \ldots . . .1 \text { 1) }
$$

If $\mathrm{F}_{\text {cal. }}>\mathrm{F}_{\text {table, }}$ then the data were homogenous

Student achievement percentage was calculated by using gain score normalized $(\mathrm{g})$ using the following formula:

$$
\% g=\frac{\text { postrest scorez-pretest wwes }}{\text { masimun xures-pretest wor sy }} \times 100 \% \text {.... 2) }
$$

Hypothesis was tested by using one way ANOVA with the following formula:

$$
\tau_{\text {cal. }}=\frac{X_{1}-X_{2}}{\sqrt{\frac{3_{1}^{2}}{n_{1}}+\frac{3 y}{n_{2}}}}
$$

$\mathrm{X}_{1}=$ student outcomes 1

$\mathrm{X}_{2}=$ student outcomes 2

$\mathrm{S}=$ standar deviation

$\mathrm{n}=$ numer of samples

\section{RESULTS AND DISCUSSION}

\section{A. Conventional Chemistry Practicum Guide Analyzet}

The three conventional Chemistry Practicum Guides A, $\mathrm{B}$ and $\mathrm{C}$ were analyzed. The workbooks covered Redox and Electrochemical reaction were analyzed based on the BSNP standard criteria [9], and the results were shown in table 2 below:

TABLE 2. AVERAGE FEASIBILITY SCORES OF THE CONVENTIONAL PRACTICUM GUIDES A, B, AND C

\begin{tabular}{ccc}
\hline Feasibility & $\begin{array}{c}\text { Average Scores of the } \\
\text { practical guide A, B, } \\
\text { and C }\end{array}$ & $\begin{array}{c}\text { Average scores of the } \\
\text { Innovative practical } \\
\text { guide }\end{array}$ \\
\hline Content & 2,57 & 3,31 \\
Language & 2,98 & 3,37 \\
Presentation & 2,92 & 3,22 \\
Graphics & 2,96 & 3,15 \\
\hline Average & 2,86 & 3,26 \\
\hline BSNP & Relatively Valid & Highly valid \\
feasibility & (no revision required) & (no revision required) \\
\hline
\end{tabular}

From the analysis of the practical guides A, B, C, some disadvantages and weaknesses were obtained including

Weakness of Practicum Guide A

Content: The scope of the material seems repetitive and incomplete; Practical implemented is not project-based and character-based; Does not contain images of chemical tools, application of elemental chemical material in everyday life, basic techniques, and basic laboratory skills.

Presentation: Does not contain KI, KD, and indicators: Theory is too short; There are few pictures

Graphicity: The design of the placement of images is less precise and giving color seems less attractive

Weakness of Practicum Guide B

Content: The scope of the material seems repetitive and incomplete; Practical implemented is not project-based and character-based; Does not contain images of chemical tools, application of elemental chemical material in everyday life, basic techniques, and basic laboratory skills.

Graphicity: The design of the placement of images is less precise and giving color seems less attractive.

Weakness of Practicum Guide C

Contents: Incompatibility of sub-material with subject matter in syllabus; The material coverage seems repetitive and incomplete; Practicum implemented is not project-based and character-based; Does not contain images of chemical tools, application of elemental chemical material in everyday life, basic techniques, and basic laboratory skills.

Language: The use of sentences in work procedures allows students to experience misconceptions

Presentation: Does not contain KI, KD, and indicators: theory is too short; there are few pictures

Graphicity: The design of the placement of images is less precise and giving color seems less attractive

\section{B. Innovative Practicum Guide and Caracter Validated}

Questionnaires were distributed to the teachers and lecturers sample selected in order to validate the Practicum Guide based integrated on the project based learning and Characters. The workbook validated contained Redox and Electrochemical Reaction and the results were listed in table 3 below: 
TABLE 3. AVERAGE SCORES OF THE VALIDATED INNOVATIVE PROJECT BASEC PRACTICUM GUIDE AND CHARACTERS

\begin{tabular}{ccccc}
\hline $\begin{array}{c}\text { Feasibilit } \\
\text { y scores } \\
\text { based on } \\
\text { the }\end{array}$ & Lecturers & Teachers & $\begin{array}{c}\text { Average } \\
\text { scores }\end{array}$ & $\begin{array}{c}\text { BSNP } \\
\text { Criteria } \\
\text { standard }\end{array}$ \\
$\begin{array}{c}\text { BSNP } \\
\text { standard }\end{array}$ & & 3,24 & 3,31 & $\begin{array}{c}\text { Highly } \\
\text { valid }\end{array}$ \\
\hline Content & 3,38 & 3,28 & 3,37 & $\begin{array}{c}\text { Highly } \\
\text { valid } \\
\text { valid }\end{array}$ \\
Language & 3,46 & 3,28 scores & 3,22 & Valid \\
$\begin{array}{c}\text { Presentati } \\
\text { on }\end{array}$ & 3,28 & 3,16 & 3,15 & \\
Graphics & 3,18 & 3,12 & Average worthiness score of BSNP $=3,26$ \\
\hline Criteria & \multicolumn{4}{c}{ No validation needed } \\
\hline
\end{tabular}

The average scores of the conventional Chemistry practicum guidance $\mathrm{A}, \mathrm{B}$ and $\mathrm{C}$ and the Innovative projectbased practicum guidance and character were shown in the following table 4 :

TABLE 4. THE AVERAGE SCORES OF THE CONVENTIONAL WORKBOOKS A, B AND C, AND INNOVATIVE PROJECT-BASED PRACTICUM GUIDE AND CHARACTER

\begin{tabular}{|c|c|c|}
\hline \multirow{2}{*}{ Feasibility } & \multicolumn{2}{|c|}{ Average Scores of the practical guide } \\
\cline { 2 - 3 } & $\begin{array}{c}\text { The practical guide A, } \\
\mathbf{B}, \text { and C }\end{array}$ & $\begin{array}{c}\text { The Innovative } \\
\text { practical guide }\end{array}$ \\
\hline Content & 2,57 & 3,31 \\
\hline Language & 2,98 & 3,37 \\
\hline Presentation & 2,92 & 3,22 \\
\hline Graphics & 2,96 & 3,15 \\
\hline $\begin{array}{c}\text { Average } \\
\text { BSNP } \\
\text { feasibility }\end{array}$ & $\begin{array}{c}\text { Relatively Valid } \\
\text { (no revision required) }\end{array}$ & $\begin{array}{c}\text { Highly valid } \\
\text { (no revision } \\
\text { required) }\end{array}$ \\
\hline
\end{tabular}

The difference between the average scores of the conventional chemistry practicum guide and the Innovative project-based practicum guide and character were shown in the Figure 3 below

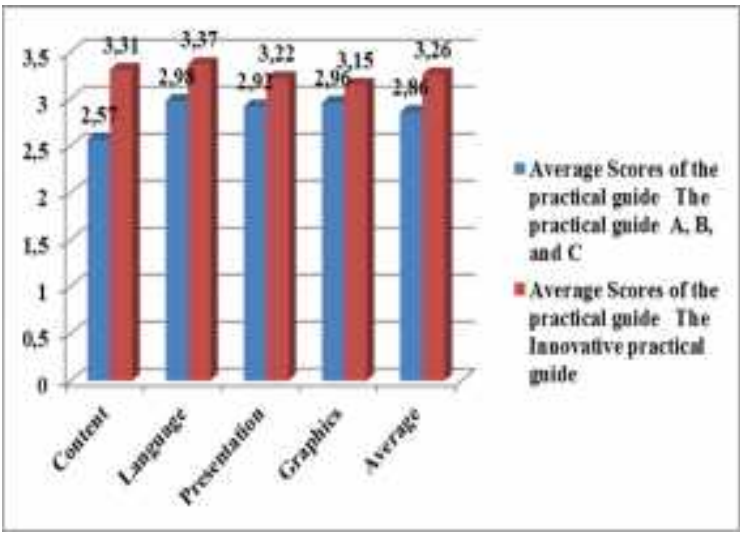

Fig. 3. Conventional practical guide and the Innovative practical guide Scores

\section{Percent Increase in Student Learning Outcomes and Hypothesis testing.}

By using the percent formula of increasing learning outcomes "g" factor (normalized gain score), obtained percent increase in chemistry class experimental learning outcomes is higher than the control class which is $81.5 \%>73.8 \%$ as in Figure 4 below.

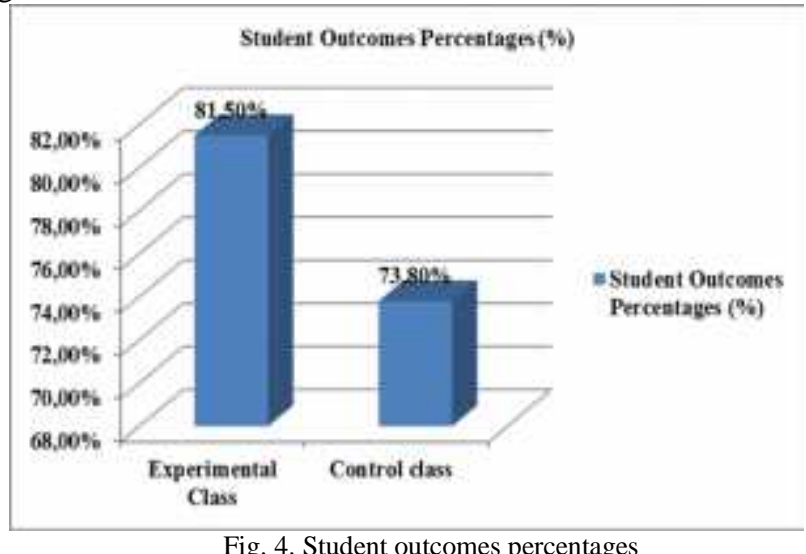

Hypothesis testing was carried out after normality and homogenity tests. One way Anova tested shown that $t_{\text {cal. }}>t_{\text {table }}$ or $(4,536>1,697)$, it means that $\mathrm{H}_{\mathrm{a}}$ accepted and the use of innovative Chemistry project-based practicum guide and character is better than the conventional practicum guide

\section{Psychomotor Assessment.}

The results of the average calculation of psychomotor values from each aspect of the experimental class are higher than the control class which is $84.64>78.42$ as shown in figure 5 below 


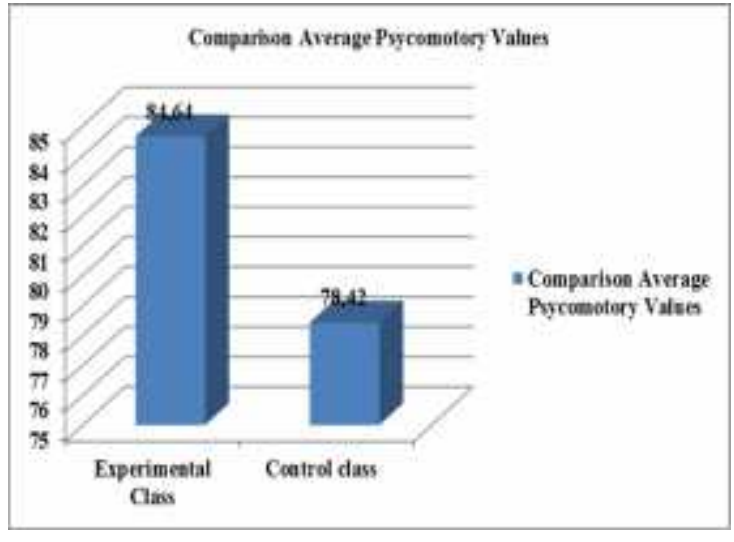

Fig. 5. Student comparison of average psychomotor values

\section{E. Affective Assessment.}

The results of the calculation of the average affective value of each aspect of the experimental class amounted to 82.78 higher than the control class of 76.38, as in Figure 6 below.

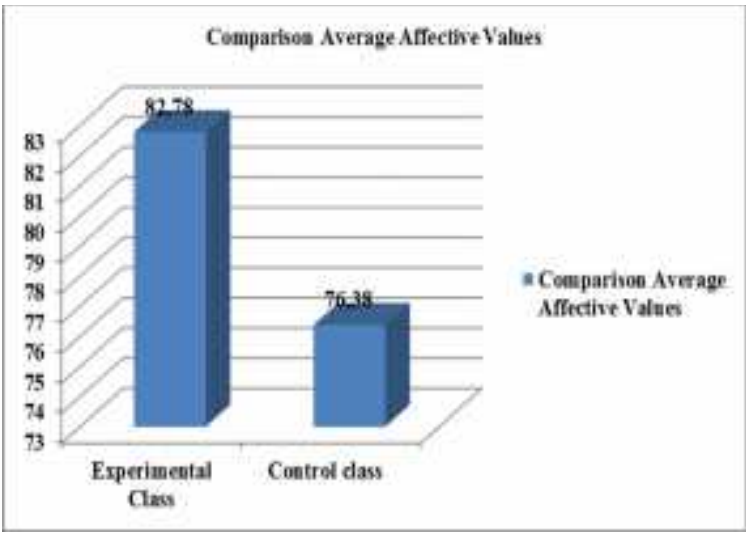

Fig. 6. Student comparison of average psychomotor values

\section{F. Discussion.}

Based on table data (3) it can be seen that the results of the analysis of the three chemistry practicum guides have different assessment scores on each component. The score for content feasibility for practicum A, B, C guides is sequentially 2.58 , 2.56 , and 2.58 , all of which are included in the less valid criteria with an average of 2.573 (necessary partial revision). Language feasibility 3.09, 3.06, and 2.78, included in the valid criteria with a mean of 2.98 (no need for revision). Feasibility of consecutive presentations $2.88,3.04$, and 2.86, included in the valid criteria with an average of 2.92 (no need for revisions). Graphical feasibility 2.98, 2.96, and 2.94, included in the valid criteria with an average of 2.96 (no need for revision). From the average score of content, language, presentation, and graphics, the average score of BSNP feasibility is 2.86 (included in valid criteria and does not need revision). Because the practicum guides $\mathrm{A}, \mathrm{B}$, and $\mathrm{C}$, are still found a number of weaknesses and shortcomings, both the feasibility of content, language, presentation, and graphics, which resulted in not achieving the feasibility of BSNP on very valid criteria, it needs to be revised.

In order for learning outcomes to foster more innovative, creative, affective, productive, collaborative, disciplined, and contributing students in the chemistry learning outcomes of students, the Redox and Electrochemical reaction Practicum Guide and Character were developed, which were designed and arranged to form project-based Practicum Guide and Character that refer to BSNP criteria standards according to the 2013 curriculum formula.

When viewed from the results of the validation in terms of the feasibility of content, language, presentation, and graphics, the guideline for the development of Redox and Electrochemical Reactions resulting from the development has met the criteria of the BSNP standard. This is evident from the acquisition of the average value of validation of the feasibility of content, the feasibility of language, the feasibility of presentation and the feasibility of graphics, has shown a high mean value of 3.26, with very valid criteria and does not need to be revised (table 4). Practical guideline results of the development have included a number of shortcomings in practical guides A, B, C, which are analyzed, namely

\section{Feasibility of Content}

The scope of the material has been prepared according to $\mathrm{KI}$ and $\mathrm{KD}$ in the syllabus, no longer repeated, and has been compiled completely; 1 . All the practicum that students do have described project-based and character-based practicum integrated learning; 2. Has contained a number of pictures of chemical tools; 3. The application of Redox and Electrochemical Reactions in daily life has been included; 4 . Already contains basic techniques and basic laboratory skills such as: how to stir the solution, mix the solution, heat the solution, smell, how to wash and filter the solution. 5. General guidelines for practicum implementation have been included, such as: pracikum rules, laboratory security, work safety equipment, and waste handling in the laboratory; 6 . Equipped with pictures and names of equipment in the laboratory; and 7. Has contained symbols of hazardous chemicals such as: properties of flammable, explosive, corrosive, dangerous, oxidizing and toxic properties.

\section{Language}

In the Practiconclusionum Guidance and Character developed, the composition and use of sentences in work procedures have used language that is easily understood, made clear and concise, so students easily understand it and do not cause misconceptions.

\section{Presentation}

In the practicum guide the results of the development, have been loaded KI, KD, and indicators, and the theory and images have been compiled according to the needs proportionally. 


\section{Graphicity}

The design of image placement, paper size, and color rendering has been adjusted, and refers to the BSNP standard criteria.

The application of Practicum Guide and Character on Redox and Electrochemical Reaction material as a result of development in learning has shown integrated project-based practicum and character learning models, and can foster student character innovative, creative, affective, productive, collaborative, responsible for work, critical thinking in stimulating emotional levels high, and discipline. As stated by [10], that in integrated practice project-based learning a standard practicum guide is needed according to BSNP criteria, which can facilitate students to get an idea of the objectives, benefits and process of practicum activities to be carried out. A good practical guide must be arranged systematically, interestingly, clearly, can be used by students independently at any time according to the needs of students.

This can be seen from the acquisition of percent increase in the learning outcomes of the experimental class higher than the control class which is $81.50 \%>73.80 \%$. Likewise, the affective and psychomotor values of the experimental group students were higher than the control class students, with the average affective grade of experimental class being $84.16>$ control class which is 78.86 , and the average psychomotor value of the experimental class was $81.36>$ control class which is 75.83. This is in accordance with the results of [11], that project-based learning is more motivated to improve student learning outcomes in the cognitive, affective, and psychomotor domains. Also research by [12], concluded that project-based learning rests on constructivist theory, enhancing critical thinking skills and skills in problem solving, synthesis, evaluation, predicting, and reflection.

\section{G. Conclusion.}

The XII Class Senior High School Practicum Guides from Publishers (A), (B), And (C) circulating in Medan needs to be innovated and developed in the form of project-based innovation that integrates practicum and character intergrated according to the 2013 curriculum. Module innovative projectbased chemistry practicum guide on redox and electrochemical reaction material of the development results have been in accordance with BSNP standards. Student chemistry learning outcomes through the implementation of project-based practicum guide and character developed in redox and electrochemical reaction higher than the reference of student hand books. The psycomotoric and affective values of students who carry out the practicum using a project-based practicum guide and character that is developed higher than the reference of the student hand books

\section{H. Recommendation.}

It recommends that Senior High School teachers should carry out teaching and learning chemistry material integrated with lab experiments and character based on the 2013 curriculum, so that the learning process based on student- centered and they will be more proactive in studying chemistry and will be able to have a better understanding the material being taught. Chemistry teachers should be trained to implement the innovative project-based developed. It is also expected to carry out in depth research on the Practicum Guide and Character for grades X, XI, and XII of Senior High Schools that met the BSNP criteria.

\section{ACKNOWLEDGMENT}

I would like to thank to the Directorate of Research and Community Service (DRPM) of the Directorate General of Strengthening Research and Development of the Ministry of Research Technology and Higher Education, for the financial assistance provided to finish the research properly. I would like also to thank to the School principal of Medan $6^{\text {th }}$ Senior High School for her assistance in providing the location of the study, to the chemistry teachers of the Medan $6^{\text {th }}$ Senior High School and the chemistry leturers of Unimed for their willingness to validate the Practical Guide and Character developed. Hopefully the project-based innovative Practical Guide and Character which met the BSNP standards can be used in Senior High Schools in Medan Indonesia.

\section{REFERENCES}

[1] Montelongo. J. A. \& Herter, R. J., Using Technology to Support Expository Reading and Writing in Science Classes, Science Activities, 2010., 47: 89-102.

[2] Situmorang, M.; Sinaga,.M.; Tarigan, D.A., Sitorus, C.J, and Tobing, A.M.L., The Affectivity of Innovated Chemistry Learning Methods to Increase Student's Achievement in Teaching of Solubility and Solubility Product, Jurnal Penelitian Bidang Pendidikan, 2011. 17(1): 29-37

[3] Fiksl. M., Flogie. A., \& Abersek. B., Innovative Teaching/Learning Methods To Improve Science, Technology And Engineering Classroom Climate And Interest, Journal Of Baltic Science Education, 2017, 16(6): 1009-1019

[4] Emery, Laura. R., \& Morgan. S.L., The application of project-based learning in bio informatics training. 2017, 13(8): 1-8.

[5] Tuysuz, C. The Effect of the Virtual Laboratory on Students'Achievement and Attitude in Chemistry. IOJES, 2010, 2(1): 37-53

[6] Sugiyono, Metode Penelitian Pendidikan (Pendekatan Kuantitatif, Kualitatif, dan R\&D), Alfabeta, Bandung, 2010. (references)

[7] Arikunto, S. Prosedur Penelitian: Suatu Pendekatan Praktik (Edisi Revisi VI). Jakarta: Rineka Cipta, 2009. . (references)

[8] BSNP. Peraturan BSNP tentang Prosedur Operasi Standar Penyelenggaraan Penilaian Buku Paket Pelajaran dan Buku Panduan Guru Pola "Inisiatif Masyarakat". Badan Standar Nasional Pendidikan. Jakarta, 2016. . (references)

[9] Permendikbud No. 59 ,Tentang Standar Kompetensi Lulusan Pendidikan Dasar dan Menengah, 2013. (references)

[10] Anwar. I., Pengembangan Bahan Ajar Bahan Kuliah Online, Direktori UPI, Bandung. 2010. . (references) 
[11] Bas Gokhan., Omer Beyhan, Effects Of Multiple Intelligences Supported Project- Based Learning On Student's Achievement Levels And Attitudes Towards English Lesson, International Electronic Journal of Elementary Education, Volume 2 issue 3. 2012, 25 November, 2013. http://www.iejee.com.

[12] Chu, S. K., Chow, K. \& Tse, S. Developing Hong Kong primary school students information literacy and IT skills through collaborative teaching and inquiry Project Based Learnig. Library \& Information Science Research. Hongkong: University of Hongkong press, 2011. 